Zeszyty Naukowe Szkoły Głównej Gospodarstwa Wiejskiego w Warszawie

Problemy Rolnictwa Światowego tom 20 (XXXV), zeszyt 1, 2020: 52-66

DOI: $10.22630 /$ PRS.2020.20.1.5

Grzegorz Maciejewski ${ }^{1}$

Uniwersytet Ekonomiczny w Katowicach

\title{
Typy gospodarstw domowych ze względu na ich zachowania na rynku żywności
}

\section{Types of Households by Their Behaviour on the Food Market}

\begin{abstract}
Synopsis. Dynamiczny rozwój rynku artykułów żywnościowych wymaga od przedsiębiorstw oraz instytucji odpowiedzialnych za politykę gospodarczą kraju ciagłego monitorowania zachowań głównego podmiotu konsumpcji na tym rynku, jakim jest gospodarstwo domowe. Jednym z rozwiązań jest prowadzenie zabiegów typologizacji. Celem artykułu jest zaprezentowanie wyników typologii gospodarstw domowych przeprowadzonych w Polsce i na Słowacji na próbie 900 gospodarstw domowych. Do delimitacji typów gospodarstw wykorzystano hierarchiczną (metoda Warda) i niehierarchiczną (metoda k-średnich) analizą skupień. W rezultacie w każdej podpróbie udało się wyodrębnić trzy typy gospodarstw domowych ze względu na ich zachowania na rynku żywności.
\end{abstract}

Słowa kluczowe: gospodarstwo domowe, typologia, rynek żywności, analiza wielowymiarowa, Polska, Słowacja

\begin{abstract}
The dynamic development of the food market requires enterprises and institutions responsible for the country's economic policy to constantly monitor the behaviour of the main consumption entity on this market, which is the household. One of the solution is to conduct typologisation procedures. The aim of the article is to present the results of household's typology conducted in Poland and Slovakia on a sample of 900 households. Hierarchical (Ward's method) and non-hierarchical (k-means method) cluster analysis was used to delimit households' types. As a result, three types of households were identified in each sub-sample by their behaviour on the food market.
\end{abstract}

Key words: household, typology, food market, multidimensional analysis, Poland, Slovakia

JEL Classification: D12, D91, M31, Q18

\section{Wprowadzenie}

W tradycyjnej teorii ekonomii gospodarstwo domowe, utożsamiane z rodziną, jest określane jako trwała i najstarsza instytucja ekonomiczna świata (Światowy, 2012, s. 56). Jest to nie tylko najstarszy, ale i najważniejszy podmiot gospodarujący, ponieważ został stworzony prawami natury, inspirował ewolucje kolejnych systemów gospodarczych i politycznych, a nauka o gospodarstwie domowym i prawach rządzących domem stanowi geneze dyscypliny ekonomia - nazwanej według etymologii greckiej oikos - dom, oikojeneja - rodzina, nomos - prawo, ustawa (Bywalec, 2009). Gospodarstwa domowe, zgłaszając popyt na towary i usługi, wpływają na cały system gospodarczy (Zalega, 2012).

\footnotetext{
${ }^{1}$ dr hab., prof. UE, Katedra Rynku i Konsumpcji, Wydział Ekonomii, Uniwersytet Ekonomiczny w Katowicach, ul. 1-go maja 50, 40-286 Katowice, e-mail: grzegorz.maciejewski@ue.katowice.pl; https://orcid.org/0000-0002-1318-0747.
} 
Dysponując określoną siłą nabywczą, zgłaszają na rynku popyt na towary i usługi mogące zaspokoić ich potrzeby. Uruchamiają tym samym koło zamachowe gospodarki, która chcąc odpowiedzieć na istniejące zapotrzebowanie przetwarza dostępne jej zasoby w dobra zaspokajające potrzeby nabywców (Gardocka-Jałowiec, 2015, s. 47). Do podstawowych potrzeb gospodarstw domowych, których realizacji poszukują na rynku należą potrzeby zaspokojenia głodu i pragnienia (Maslow, 2018), zgłaszane jako popyt na różnego rodzaju artykuły żywnościowe.

Gospodarstwa domowe są nie tylko najstarszym, ale i najbardziej powszechnym podmiotem gospodarującym. Tworzą one grupę jednostek silnie heterogenicznych. Podstawę zróżnicowania gospodarstw domowych stanowi z jednej strony szereg cech społecznych, demograficznych, ekonomicznych, kulturowych i innych tych podmiotów, z drugiej - odmienne sposoby postępowania członków gospodarstw domowych na rynku, co uwidacznia się w poziomie i strukturze wydatków tych podmiotów (Piekut, 2017). Zróżnicowanie cech i odmienność sposobów zachowań powoduje, że chcący odpowiedzieć na zapotrzebowania gospodarstw domowych producenci i sprzedawcy stoją przed dużą trudnością dostosowania swojej oferty podażowej do tak niejednorodnej i zmiennej grupy podmiotów. Pewnym rozwiązaniem tego problemu jest przeprowadzenie typologizacji gospodarstw domowych ze względu na ich cechy, postawy, preferencje czy zachowania rynkowe.

Rozwój badań nad typologią gospodarstw domowych stał się możliwy dzięki rozwojowi teorii zachowań rynkowych konsumentów oraz postępowi w metodach statystycznych i ekonometrycznych połączonych z niespotykanymi dotąd możliwościami przetwarzania ogromnych ilości danych pozwalających na prowadzenie analiz wielowymiarowych (Kusińska, 2014, s. 90). Celem niniejszego artykułu jest zaprezentowanie wyników dwóch empirycznych typologii gospodarstw domowych przeprowadzonych na podstawie badań zachowań gospodarstw domowych na jednym $\mathrm{z}$ najbardziej dynamicznie rozwijających się obecnie rynków - rynku artykułów żywnościowych. Prezentowane typologie opierają się zatem nie na analizie cech (społecznych, demograficznych, ekonomicznych), postaw czy preferencji badanych podmiotów, a na ich zachowaniach rynkowych. W badaniach wzięło udział 600 gospodarstw domowych z Polski (województwa mazowieckie i śląskie) oraz 300 ze Słowacji.

Artykuł ma charakter badawczy. Podstawy źródłowe prezentowanych rozważań stanowi literatura przedmiotu oraz badania pierwotne autora, przeprowadzone w ramach projektu badawczego pt. „Zmiany modeli konsumpcji żywności w Polsce”, realizowanego w latach 2018 - 2019 i finansowanego ze środków MNiSW. Opisane typy gospodarstw domowych wyodrębniono na podstawie metod analizy wielowymiarowej (hierarchicznej i niehierarchicznej analizy skupień). W pierwszej części pracy przedstawiono istotę typologii gospodarstw domowych oraz znaczenie jakie odgrywa w procesach rozpoznawania realizowanych w gospodarstwach wzorców konsumpcji. Wskazano tam także na dużą aplikacyjność zabiegu typologizacji. W części drugiej opisano wykorzystane agregaty danych i zastosowane do ich analizy metody statystyczne. W trzeciej i czwartej części pracy zaprezentowano rezultaty przeprowadzonych typologii. Opracowanie kończy podsumowanie zawierające najważniejsze wnioski z przeprowadzonych badań. Wnioski płynące $\mathrm{z}$ zaprezentowanego materiału nie wyczerpują w pełni podjętego tematu, mogą jednak stanowić głos w dyskusji nad rozwojem badań i analiz rynkowych zachowań gospodarstw domowych, realizowanymi przez gospodarstwa domowe wzorcami 
konsumpcji żywności oraz strategiami marketingowymi przedsiębiorstw kierujących swoją ofertę żywnościową do wyodrębnionych typów gospodarstw domowych.

\section{Przegląd literatury}

Złożoność kwestii przeprowadzania typologii wynika z różnego rozumienia samego pojęcia typologii, jak też akcentowania różnych jej aspektów podporządkowanych intencjom samych badaczy. Najpowszechniej typologię określa się jako szeregowanie i logiczne porządkowanie elementów danego zbioru (przedmiotów, zjawisk itp.), według zasady porównywania ich cech $\mathrm{z}$ cechami elementów uznanych jako typy $\mathrm{w}$ obrębie określonego zbioru (PWN, 2019). Typologia jest zatem efektem zastosowania określonych technik badania i analizowania przebiegu zjawiska. Stosuje się ją dla uproszczenia danych i przyłączenia poszczególnych jednostek do grup jednostek mało się od siebie różniących. Powinno to następować w taki sposób, aby utrata informacji charakteryzujących badaną populację była jak najmniejsza (Smyczek i Sowa, 2005). W rezultacie tworzone są typy, a więc w miarę jednorodne (homogeniczne) grupy jednostek wyodrębnionych ze względu na przyjęty zestaw kryteriów. Kryteriami tymi mogą być główne bądź specyficzne cechy jednostek poddawanych typologizacji opisywanych za pomocą zbiorów zmiennych przyczynowych: demograficznych, społecznych, psychologicznych, ekonomicznych etc. (Kieżel, 2010). Typ definiowany jest również jako pewne zjawisko, własność lub konfiguracja zjawisk czy własności analizowanych przedmiotów, zdarzeń czy procesów, z takich czy innych względów uznanych za na tyle ważne, że warte specjalnej uwagi i wyodrębnienia $\mathrm{w}$ aparaturze pojęciowej (Nowak, 2012). Typologia zatem nie tylko prowadzi do uporządkowanego i syntetycznego obrazu badanej rzeczywistości, ale pozwala na (Saran, 2014, s. 24):

- dokonywanie dalszych analiz - porównań jednostek i wyodrębnionych zbiorowości w szerszym kontekście;

- poszukiwanie zależności zmiennej typologicznej od innych zmiennych uwzględnionych w badaniach;

- dokonywanie opisu i wyprowadzania twierdzeń oceniających i normatywnych.

Odgrywa więc nie tylko rolę $\mathrm{w}$ budowaniu naukowych teorii, ale ma także duże znaczenie w formułowaniu zasad dotyczących funkcjonowania praktyki gospodarczej.

$\mathrm{W}$ badaniach rynkowych i marketingowych, gdzie obiektem typologizacji jest konsument indywidualny typologię ujmuje się jako metodę poznania naukowego, pozwalającą na wyodrębnienie typów badanej zbiorowości i ich opisanie (Smyczek i Sowa, 2005; Kusińska, 2009; Kieżel, 2010). Typologię w takim przypadku opiera się na zbiorze zmiennych przyjętych a priori (typologia aprioryczna) lub na zbiorze zmiennych zweryfikowanych empirycznie (typologia empiryczna) (Kusińska, 1990). Celem typologii konsumentów jest wyróżnienie typów tych podmiotów i ujawnienie zespołu cech charakterystycznych dla każdego z nich. Kryteriów wyodrębniania grup typologicznych konsumentów może być wiele (Gutkowska, Ozimek i Laskowski, 2001; Smyczek i Sowa, 2005; Kusińska, 2009; Kieżel, 2010; Sowa, 2018):

- cechy społeczne, demograficzne, ekonomiczne, osobowościowe czy inne;

- rodzaj, hierarchia, poziom i pilność zgłaszanych potrzeb oraz preferencje i motywy ich zaspakajania; 
- postawy wobec podmiotów (np. producentów i ich marek), rzeczy (np. oferowanych produktów), zjawisk czy idei (np. zrównoważona konsumpcja);

- zachowania na rynku, a nawet poszczególne elementy tych zachowań, jak decydowanie, wybieranie, nabywanie.

Przeprowadzenie typologii konsumentów sprowadza się do wyodrębnienia względnie jednorodnych typów konsumentów na podstawie jednego lub kilku kryteriów jednocześnie, a następnie ustalenia liczebności oraz dokonania charakterystyki wyodrębnionych grup typologicznych (Jaciow i Wolny, 2011). Odnosząc przywołaną definicję do gospodarstw domowych można przyjąć za Piekut (2017), że typologia gospodarstw domowych to zabieg systematyzujący, polegający na kwalifikowaniu gospodarstw domowych do jednego lub więcej typów. Dokonanie typologizacji gospodarstw domowych pozwala na porównywanie poszczególnych typów między sobą oraz wskazanie cech charakterystycznych tylko dla danego typu. Za celowością wyodrębniania takich grup i opisu zaobserwowanych, typowych dla nich wzorów zachowań przemawiają tak względy poznawcze, jak i względy praktyczne. Przeprowadzenie typologii daje bowiem możliwość przedstawienia swoistych cech badanych gospodarstw domowych i mnogości różnych rodzajów ich zachowań. Tworzy także informacje przydatne przedsiębiorstwom do budowy skutecznych strategii marketingowych i instytucjom kształtującym politykę gospodarczą kraju (Światowy, 2006; Piekut, 2008).

W literaturze przedmiotu znaleźć można przykłady zabiegów typologizacji już na początku ubiegłego stulecia. Pierwsze prace dotyczące typologii powstawały na gruncie antropologii (von Ginneken,1907; Oppenheim, 1911) oraz na gruncie psychologii i pedagogiki (Jaensch, 1928; Shuey, 1937). Za jedną z pierwszych prób opisania problematyki przeprowadzania typologii konsumentów uznać należy prace autorstwa Myersa i Nicosii z końca lat 60. XX wieku (Myers i Nicosia,1968). W Polsce badania nad typologią konsumentów prowadzone były od połowy lat 80. ubiegłego wieku. Zapoczątkowano je Instytucie Rynku Wewnętrznego i Konsumpcji (IRWiK) w Warszawie. Pierwsze badania dotyczyły typologii konsumentów według zachowań na rynku, z uwzględnieniem i odrębnym ujęciem kryterium diagnostycznego, pozwalającego na delimitację klastrów wyznaczających typy konsumentów, w odniesieniu do pięciu podstawowych grup potrzeb. Były to potrzeby związane $\mathrm{z}$ wyżywieniem, ubraniem, wypoczynkiem i wyposażeniem mieszkania w dobra trwałego użytku (Kusińska, 1992). Po roku 1990 badania nad typologią konsumentów rozwijane były także w innych ośrodkach akademickich (m.in. na Uniwersytecie Ekonomicznym w Katowicach, SGGW w Warszawie, SGH w Warszawie), jak i w instytutach i agencjach badań marketingowych powiązanych $\mathrm{z}$ międzynarodowymi grupami badawczymi i firmami konsultingowymi (m.in. GfK Polonia, Pentor Research, IQS, Young and Rubicam). Rozwój rynku europejskiego i udział w tym rynku także polskiej gospodarki każe także zwrócić uwagę na powstałe typologie eurokonsumentów. Do najbardziej znanych badań w tym obszarze należą te zrealizowane przez Centre de Communication Avance (CCA), znane jako EuroStyl (Komor, 2011; CCA, 2019). Typologię eurokonsumentów przeprowadził też szwajcarski Research Institute on Social Change (RISC) (Komor, 2000). W ostatnich latach interesująca typologię wiejskich gospodarstw domowych przedstawiła Piekut (2017) natomiast $\mathrm{w}$ literaturze zagranicznej zwrócić można uwagę na typologie związane $\mathrm{z}$ rynkiem żywności, dotyczące: sklepów z artykułami spożywczymi (Diansheng i Hayden, 2012), konsumpcji rodzinnych gospodarstw domowych (Kruger, 2014), żywności 
spożywanej w gospodarstwach domowych (Magadze i in., 2017) czy konsumentów dopuszczających do marnotrawstwa żywności (Di Talia, Simeone i Scarpato, 2019). Prace te jednak nie dotykają kwestii typologii gospodarstw domowych ze względu na ich zachowania na rynku żywności. Prezentowane opracowanie stanowi próbę wypełnienia luki w tym obszarze wiedzy, co jednak należy zaznaczyć - z uwagi na ograniczone środki próbę wstępną.

\section{Dane i metody}

Podstawę źródłową empirycznej części opracowania stanowią badania bezpośrednie, przeprowadzone w ramach projektu badawczego pt. „Zmiany modeli konsumpcji żywności w Polsce", realizowanego w Katedrze Rynku i Konsumpcji UE w Katowicach w latach 2018-2019 i finansowanego przez MNiSW. Część badań przeprowadzonych w ramach projektu dotyczyła konsumpcji żywności gospodarstw domowych, w tym ich zachowań na rynku artykułów żywnościowych. Badania te wykonane zostały metodą ankiety, techniką ankiety rozdawanej. Narzędziem badawczym był kwestionariusz składający się z 8 pytań merytorycznych oraz pytań metryczkowych. Pytania merytoryczne sformułowane zostały w formie skal porządkowych, dwubiegunowych, siedmiostopniowych oraz skal przedziałowych. Oceny rzetelności użytych skal dokonano obliczając dla nich współczynnik alfa Cronbacha i jeśli przyjąć za dopuszczalny poziom współczynnika $\alpha>$ 0,7 - jak proponują to Nunnally i Bernstein (za: Henson, 2001), to wykorzystane w badaniu skale można uznać za rzetelne. Pytania merytoryczne podporządkowane były ściśle celom badania i służyły identyfikacji postaw oraz zachowań gospodarstw domowych na rynku artykułów żywnościowych. Pytania metryczkowe umożliwiły opis jednostek, które weszły do próby ze względu na ich cechy demograficzne, ekonomiczne i społeczne.

Badania przeprowadzono wśród nielosowo dobranych osób, reprezentujących swoje gospodarstwa domowe z województwa mazowieckiego i śląskiego oraz ze Słowacji ${ }^{2}$. Decyzja o wyborze nielosowego doboru do próby podyktowana była przede wszystkim brakiem odpowiedniego operatu losowania oraz koniecznością ograniczenia kosztów badań. Do próby kwalifikowano osoby pełnoletnie, odpowiedzialne za dokonywanie zakupów żywności i przygotowanie posiłków.

W wyniku przeprowadzonych badań oraz po weryfikacji formalnej otrzymanego materiału badawczego do analiz zakwalifikowano $900 \mathrm{w}$ pełni poprawnie wypełnionych kwestionariuszy (po $300 \mathrm{z}$ województw mazowieckiego i śląskiego oraz 300 ze Słowacji).

$\mathrm{W}$ próbie $\mathrm{z}$ województwa śląskiego znalazły się różnoliczne gospodarstwa domowe. Najczęściej były to gospodarstwa dwuosobowe $(25,7 \%)$, czteroosobowe $(21,7 \%)$ i trzyosobowe $(20,7 \%)$. Stosunkowo mniej liczniej reprezentowane były gospodarstwa jednoosobowe $(18,0 \%)$ oraz pięcio- i więcej osobowe $(14,0 \%)$. W próbie przeważały gospodarstwa domowe z miast różnej wielkości $(87,3 \%)$, wśród których najliczniejszą grupę stanowiły gospodarstwa z miast liczących od 101 do 200 tys. mieszkańców. Wiejskie

\footnotetext{
${ }^{2}$ Autor chciałby w tym miejscu podziękować za pomoc merytoryczną i techniczną w przeprowadzeniu badania w województwie mazowieckim prof. dr hab. Irenie Ozimek z Katedry Polityki Rozwoju i Marketingu SGGW w Warszawie oraz doc. Ing. Pavolowi Kita z Katedry Marketingu Uniwersytetu Ekonomicznego w Bratysławie za pomoc merytoryczną i techniczną w przeprowadzeniu badania na Słowacji oraz pomoc w thumaczeniu kwestionariusza na język słowacki. Tłumaczenie kwestionariusza odbyło się zgodnie z zasadami ekwiwalencji badań międzynarodowych o czym piszą m.in. Jaciow (2018) i Barska (2019).
} 
gospodarstwa domowe biorące udział w badaniu stanowiły 12,7\% ankietowanych. Uczestnicy badania, zapytani o ocenę sytuacji materialnej swojego gospodarstwa domowego, najczęściej przyznawali, że jest ona dobra lub przeciętna (odpowiednio $43,0 \%$ i $38,0 \%$ ). Złą lub bardzo złą sytuację zadeklarowało 5,0\%, natomiast bardzo dobrą - 14,0\% badanych. Ankietowani w zdecydowanej większości legitymowali się wykształceniem średnim. Najmłodszy respondent liczył 19 lat - najstarszy 82 lata. Mediana wieku pani domu wyniosła 45 lat, pana domu - 46 lat.

W próbie polskich gospodarstw domowych znaleźli się respondenci z różnolicznych jednostek. Najczęściej były to gospodarstwa 4-osobowe (30,2\%) oraz 2 i 3-osobowe (odpowiednio 20,7\% i 20,8\%). Stosunkowo mniej liczniej reprezentowane były gospodarstwa 1-osobowe $(16,0 \%)$ oraz 5 - i więcej osobowe $(12,3 \%)$. W próbie przeważały miejskie gospodarstwa domowe $(81,0 \%)$, wśród których najliczniejszą grupę stanowiły jednostki z miast liczących powyżej 200 tys. mieszkańców. Wiejskie gospodarstwa domowe stanowiły 19,0\% ankietowanych. Uczestnicy badania, zapytani o ocenę sytuacji materialnej swojego gospodarstwa domowego, najczęściej przyznawali, że jest ona dobra lub przeciętna (odpowiednio 47,5\% i 34,5\%). Złą lub bardzo złą sytuację zadeklarowało 2,8\%, natomiast bardzo dobrą - 15,2\% badanych. Ankietowani w zdecydowanej większości legitymowali się wykształceniem średnim. Najmłodszy respondent liczył 19 lat - najstarszy 82 lata. Mediana wieku pani domu wyniosła 45 lat, pana domu - 48 lat.

W próbie badanych ze Słowacji najwięcej było gospodarstw 4-osobowych $(27,8 \%)$ i 2-osobowych (26,1\%). Niewiele mniej zaobserwowano także gospodarstw 3-osobowych $(24,4 \%)$. Najmniej liczny odsetek w badanej próbie stanowiły gospodarstwa osób samotnych oraz 5- i więcej osobowe (odpowiednio 12,4\% i 9,4\%). W badanej próbie wiejskie gospodarstwa domowe stanowiły $18,4 \%$ gospodarstw. Pozostałe to gospodarstwa miejskie z miast liczących do 50 tys. mieszkańców (27,1\%), od 51-100 tys. (26,4\%) i z miast liczących więcej niż 100 tys. mieszkańców (28,1\%). Uczestnicy badania ze Słowacji, zapytani o ocenę sytuacji materialnej swojego gospodarstw domowego, najczęściej przyznawali, że jest ona dobra (48,8\%) lub przeciętna (29,5\%). Złą lub bardzo złą sytuację zadeklarowało 1,8\%, natomiast bardzo dobrą - 20,4\%. Badani w większości legitymowali się wykształceniem średnim. Najmłodszy respondent liczył 21 lat - najstarszy 89. Mediana wieku pani domu wyniosła 46 lat, pana domu - 48 lat.

W przeprowadzonych próbach typologii wykorzystano 11 zmiennych diagnostycznych charakteryzujących zachowania nabywcze gospodarstw domowych na rynku artykułów żywnościowych. ${ }^{3}$ Tworzyły one siedmiostopniową skalę porządkową, gdzie liczba -3 oznaczała odpowiedź „całkowicie się nie zgadzam”, a +3 odpowiedź „całkowicie się zgadzam”. Wartość alfa Cronbacha wyniosła 0,764 (wersja polska) oraz 0,811 (wersja słowacka) co świadczy o dobrym poziomie rzetelności zastosowanej skali.

Do wyodrębnienia względnie homogenicznych grup (typów) gospodarstw domowych ze względu na ich zachowania na rynku artykułów żywnościowych zastosowano analizę skupień (cluster analysis), której liczne zastosowania w badaniach rynkowych i

\footnotetext{
${ }^{3}$ Zmienne zapisane zostały w sposób następujący: 1. Zakupu żywności dokonujemy na podstawie wcześniej sporządzonej listy produktów. 2. Przy zakupie żywności zwracamy uwagę na jej składniki. 3. Przy zakupie żywności zwracamy uwagę na termin przydatności do spożycia. 4. Przy zakupie żywności zwracamy uwagę na jej walory smakowo-zapachowe. 5. Przy zakupie żywności zwracamy uwagę na jej cenę. 6. Żywność kupujemy w sklepach, do których mamy zaufanie. 7. Kupujemy żywność przez internet. 8. Przy zakupie żywności zwracamy uwagę na rodzaj opakowania. 9. Przy zakupie żywności zwracamy uwagę na jej pochodzenie. 10. Informujemy się o nowych ofertach żywnościowych. 11. Przed zakupem zastanawiamy się czego potrzebujemy.
} 
marketingowych wymienia m.in. Walesiak (2004, s. 344-347). Prace nad opisywanymi typologiami przeprowadzone zostały według trzech etapów zaproponowanych przez Kusińską (2009, s. 88-89):

- Etap I - przyjęcie kryteriów typologii, czyli dokonanie wyboru zestawu zmiennych diagnostycznych na podstawie których zostanie przeprowadzona typologia.

- Etap II - delimitacja, czyli grupowanie gospodarstw domowych według przyjętego kryterium diagnostycznego, za pomocą analizy skupień.

- Etap III - ocena i wersyfikacja uzyskanych wyników oraz opracowanie profili wyodrębnionych skupień, z uwzględnieniem zmiennych aktywnych i opisowych (charakterystyk społecznych, ekonomicznych i demograficznych).

Do przeprowadzenia typologii wykorzystano 11 zmiennych diagnostycznych, o których była już wcześniej mowa. Wyodrębnienia typów gospodarstw domowych przeprowadzono w dwóch krokach. Pierwszym była analiza skupień metodą Warda (hierarchiczna) zastosowana z kwadratem odległości euklidesowej, drugim - niehierarchiczna analiza skupień metodą kśrednich. Wykorzystanie obydwu metod wynika z ograniczeń metodologicznych (Gatnar i Walesiak, 2009, s. 407-421). Analiza niehierarchiczna jest mniej wrażliwa na obserwacje odbiegające od normy oraz niepoprawne zmienne, co pozwala na otrzymanie lepszych rezultatów. Wymaga ona jednak podania liczby docelowej wyodrębnianych grup jednostek, a ta nie jest $\mathrm{z}$ góry ustalona. Aby uzyskać te informacje należy posłużyć się najpierw hierarchiczną analizą skupień (Piekut, 2017). Analiza współczynnika aglomeracji oraz dendrogramu, uzyskana za pomocą analizy warstwowej metodą Warda, doprowadziły do wyboru (w obu przypadkach) trzech typów gospodarstw domowych (pierwszy wyraźny skok odległości aglomeracyjnej). Po przeprowadzeniu analizy niehierarchicznej ustalono ostatecznie ich centroidy (środki ciężkości) i dokonano przyporządkowania każdego obiektu do grupy, której centroid jest mu najbliższy (Everitt i in., 2011), następnie wyodrębnionym typom nadano subiektywne nazwy, które w najlepszy sposób oddają cechy behawioralne badanych jednostek przypisanych do danych typów. Wszelkie obliczenia dokonano przy wykorzystaniu oprogramowania IBM SPSS Statistics 25.

\section{Wyniki badań nad typologią gospodarstw domowych w województwach mazowieckim i śląskim}

W wyniku przeprowadzonych analiz wyodrębniono trzy względnie homogeniczne typy gospodarstw domowych. Wielkość typów (liczba obserwacji w każdym typie) wraz z ich nazwami pokazana została w tabeli 1 .

Tabela 1. Nazwy i wielkości wyodrębnionych typów - województwa mazowieckie i śląskie

Table 1. Names and sizes of extracted types - Masovian Voivodeship and Silesian Voivodeship

\begin{tabular}{c|l|c|c}
\hline Klaster / Typ & \multicolumn{1}{|c|}{ Nazwa } & Liczba obserwacji & $\begin{array}{c}\text { Procent } \\
\text { obserwacji }\end{array}$ \\
\hline I & Zajęci innymi sferami życia & 163 & 27,2 \\
\hline II & Świadomi i racjonalni & 261 & 43,5 \\
\hline III & $\begin{array}{l}\text { Wygodni, nie przywiązujący zbyt dużej } \\
\text { wagi do żywności i żywienia }\end{array}$ & 176 & 29,3 \\
\hline Ważne & 600 & 100,0 \\
\hline \multicolumn{2}{r}{ Braki } & 0 & 0,0 \\
\hline
\end{tabular}

Źródło: Badania własne. 
W pierwszej wyodrębnionej grupie (typ I) znalazły się gospodarstwa domowe, które generalnie stosunkowo najrzadziej, spośród wyróżnionych typów, podejmowały działania wymieniane na poszczególnych itemach skali - tab. 2. Rzadziej bowiem, niż gospodarstwa z pozostałych klastrów, rozmawiają o nowych ofertach żywnościowych $(66,3 \%$ odpowiedzi negatywnych); zwracają uwagę na rodzaj opakowania żywności $(63,7 \%)$, jej pochodzenie $(47,5 \%)$ czy walory smakowe $(11,3 \%)$. Najrzadziej także deklarują zainteresowanie ceną nabywanej przez nie żywności (12,5\%). Co warte odnotowania $100 \%$ badanych gospodarstw typu I nie dokonuje zakupów żywności przez internet i najwyraźniej nie jest tą formą sprzedaży zainteresowane (wszystkie odpowiedzi -3). Pierwszy wyróżniony typ tworzą głównie gospodarstwa 4- oraz 5- i więcej osobowe (łącznie stanowią 46,7\% gospodarstw typu I), ze wsi i mniejszych miast, liczących do 100 tys. mieszkańców (łącznie 56,3\%), o przeciętnej sytuacji materialnej (40,8\%). W blisko 80\% tego typu gospodarstw panie domu mają największy wpływ na to, jaka żywność zostanie kupiona i podana domownikom. One bowiem wybierają kupują i przygotowują posiłki. Panie domu gospodarstw typu I to najczęściej osoby między 36 a 49 rokiem życia (45,5\% wszystkich pań domu tego typu), aktywne zawodowo, wychowujące dzieci. Najczęściej w tym typie gospodarstw domowych spożywana jest żywność funkcjonalna (68,9\% deklaruje, że spożywana jest przynajmniej kilka razy w miesiącu lub częściej). Gospodarstwa tworzące typ I można by zatem określić mianem ,zajętych innymi sferami życia”. W pobranej próbie stanowią oni najmniej liczną grupę badanych $(27,2 \%)$.

Gospodarstwa domowe skupione w typie II określić można by mianem ,świadomych i racjonalnych". Stanowią one najliczniejszą wyodrębniona grupę $(43,5 \%$ ogółu badanych gospodarstw). Są to gospodarstwa częściej, niż w innych typach, tworzone przez panie domu w wieku 35 lat i młodszym (38,2\%). To głównie gospodarstwa domowe 2- i 3-osobowe (odpowiednio 32,0\% i 24,2\%), z większych miast (miasta liczące od 100 do 200 tys. mieszkańców - 33,8\% i miasta powyżej 200 tys. mieszkańców - 25,4\%). W tym typie gospodarstw najczęściej $\mathrm{z}$ pośród wszystkich typów o wyborze danych artykułów żywnościowych decydują wszyscy domownicy (10,6\%), mimo tego zakupy i przygotowanie posiłków najczęściej także spoczywa na barkach pani domu (odpowiednio 82,4\% i 85,9\%). Spośród wyodrębnionych grup gospodarstw, członkowie gospodarstw typu II odżywiają się najzdrowiej. Najczęściej bowiem spożywana jest tutaj żywność ekologiczna $(53,5 \%$ przynajmniej kilka razy w miesiącu i częściej) oraz domowe przetwory $(88,7 \%)$. Stosunkowo najmniej spożywa się żywności wygodnej (nie jada się w 19,7\% gospodarstw) i funkcjonalnej $(14,1 \%)$. Gospodarstwa domowe skupione w typie II rzadziej, niż inne gospodarstwa, zwracają uwagę tylko na cenę żywności oraz dokonują jej zakupów przez internet - tab. 2.

Trzeci, ostatni wyodrębniony typ gospodarstw domowych, stanowią jednostki, które najmniej ze wszystkich badanych zdają się interesować tym co jedzą. Najrzadziej bowiem, z wszystkich typów, zwracają uwagę na składniki żywności (73,1\% przedstawicieli tego typu gospodarstw deklaruje, że tego nie robi), najrzadziej także planują zakupy sporządzając listę potrzebnych produktów (nie robi tego 64,1\%). Najrzadziej także zwracają uwagę na termin przydatności do spożycia nabywanych artykułów (76,9\% zwraca uwagę) i najrzadziej też zwracają uwagę na kwestię zaufania do sprzedawcy od którego nabywają żywność (79,5\%). Częściej natomiast, niż inne typy gospodarstw, zwracają uwagę na cenę żywności (robi to $93,6 \%)$ i dokonują jej zakupów przez internet $(5,1 \%)$ - tab. 2. W gospodarstwach typu III stosunkowo najrzadziej spożywana jest żywność ekologiczna (48,7\% spożywa ją okazjonalnie, a 16,7,\% nie je wcale) oraz domowe przetwory. Najczęściej spożywana jest natomiast żywność wygodna (69,2\% przynajmniej kilka razy w miesiącu lub częściej) i żywność funkcjonalna (kilka razy w miesiącu i częściej 55,1\%, okazjonalnie 39,7\%). W 
gospodarstwach III typu najwięcej jest gospodarstw jednoosobowych $(19,2 \%)$ prowadzonych głównie przez mężczyzn. Duży odsetek stanowią także gospodarstwa domowe 4-osbowe $(30,8 \%)$, w których Panie domu liczą 50 i więcej lat $(38,0 \%)$, aktywnych zawodowo z dorosłymi dziećmi pozostającymi we wspólnym gospodarstwie domowym. Gospodarstwa te, częściej niż pozostałe, funkcjonują w miastach liczących od 100 do 200 tys. mieszkańców $(29,7 \%)$. Gospodarstwa te stanowia grupę blisko $30 \%$ ogółu badanych. Określić można by je mianem „wygodnych, nie przywiązujących zbyt dużej wagi do żywności i żywienia”.

Tabela 2. Charakterystyka wyodrębnionych typów gospodarstw domowych według ich zachowań na rynku żywności - województwa mazowieckie i śląskie ( $\mathrm{N}=600$, w \%)

Table 2. Characteristics of extracted types of households according to their behaviour on the food market Masovian Voivodeship and Silesian Voivodeship ( $\mathrm{N}=600$, in \%)

\begin{tabular}{|c|c|c|c|c|}
\hline \multirow[t]{2}{*}{ Wyszczególnienie } & \multirow[t]{2}{*}{ Odpowiedź } & \multicolumn{3}{|c|}{ Typy gospodarstw domowych } \\
\hline & & $\mathrm{I}$ & II & III \\
\hline \multirow{3}{*}{$\begin{array}{l}\text { Zakupu żywności dokonujemy na podstawie } \\
\text { wcześniej sporządzonej listy produktów. }\end{array}$} & twierdząca & 26,3 & 51,4 & 17,9 \\
\hline & ani tak ani nie & 18,8 & 14,1 & 17,9 \\
\hline & przecząca & 55,0 & 34,5 & 64,1 \\
\hline \multirow{3}{*}{$\begin{array}{l}\text { Przy zakupie żywności zwracamy uwagę na jej } \\
\text { składniki. }\end{array}$} & twierdząca & 83,8 & 84,5 & 6,1 \\
\hline & ani tak ani nie & 11,3 & 7,7 & 73,1 \\
\hline & przecząca & 5,0 & 7,7 & 73,1 \\
\hline \multirow{3}{*}{$\begin{array}{l}\text { Przy zakupie żywności zwracamy uwagę na } \\
\text { termin przydatności do spożycia. }\end{array}$} & twierdząca & 92,5 & 97,9 & 76,9 \\
\hline & ani tak ani nie & 3,8 & 0,7 & 6,4 \\
\hline & przecząca & 3,8 & 1,4 & 16,7 \\
\hline \multirow{3}{*}{$\begin{array}{l}\text { Przy zakupie żywności zwracamy uwagę na jej } \\
\text { walory smakowo-zapachowe. }\end{array}$} & twierdząca & 80,0 & 93,7 & 76,9 \\
\hline & ani tak ani nie & 8,8 & 4,2 & 12,8 \\
\hline & przecząca & 11,3 & 2,1 & 10,3 \\
\hline \multirow{3}{*}{$\begin{array}{l}\text { Przy zakupie żywności zwracamy uwagę na jej } \\
\text { cenę. }\end{array}$} & twierdząca & 77,5 & 89,4 & 93,6 \\
\hline & ani tak ani nie & 10,0 & 5,6 & 2,6 \\
\hline & przecząca & 12,5 & 4,9 & 3,8 \\
\hline \multirow{3}{*}{$\begin{array}{l}\text { Żywność kupujemy w sklepach, do których } \\
\text { mamy zaufanie. }\end{array}$} & twierdząca & 90,0 & 97,2 & 79,5 \\
\hline & ani tak ani nie & 5,0 & 2,1 & 14,1 \\
\hline & przecząca & 5,0 & 0,7 & 6,4 \\
\hline \multirow[t]{3}{*}{ Kupujemy żywność przez internet. } & twierdząca & - & 4,2 & 5,1 \\
\hline & ani tak ani nie & - & 91,5 & 89,7 \\
\hline & przecząca & 100,0 & 91,5 & 89,7 \\
\hline \multirow{3}{*}{$\begin{array}{l}\text { Przy zakupie żywności zwracamy uwagę na } \\
\text { rodzaj opakowania. }\end{array}$} & twierdząca & 17,5 & 73,9 & 50,0 \\
\hline & ani tak ani nie & 18,8 & 17,6 & 11,5 \\
\hline & przecząca & 63,7 & 8,5 & 38,5 \\
\hline \multirow{3}{*}{$\begin{array}{l}\text { Przy zakupie żywności zwracamy uwagę na jej } \\
\text { pochodzenie. }\end{array}$} & twierdząca & 47,5 & 87,3 & 42,3 \\
\hline & ani tak ani nie & 5,0 & 7,7 & 17,9 \\
\hline & przecząca & 47,5 & 4,9 & 39,7 \\
\hline \multirow{3}{*}{$\begin{array}{l}\text { Informujemy się o nowych ofertach } \\
\text { żywnościowych. }\end{array}$} & twierdząca & 15,0 & 78,9 & 46,2 \\
\hline & ani tak ani nie & 18,8 & 16,2 & 20,5 \\
\hline & przecząca & 66,3 & 4,9 & 33,9 \\
\hline \multirow{3}{*}{$\begin{array}{l}\text { Przed zakupem zastanawiamy się czego } \\
\text { potrzebujemy. }\end{array}$} & twierdząca & 91,3 & 96,5 & 83,3 \\
\hline & ani tak ani nie & 5,0 & 3,5 & 10,6 \\
\hline & przecząca & 3,8 & - & 6,4 \\
\hline
\end{tabular}

Uwaga: Badani zaznaczali swoje odpowiedzi na siedmiostopniowej skali, gdzie +3 oznaczało całkowicie się zgadzam, a -3 - całkowicie się nie zgadzam. Kategoria „odpowiedź twierdząca” powstała z połączenia odpowiedzi zaznaczonych na dodatnich liczbach skali, natomiast kategoria „odpowiedź przecząca” z połączenia odpowiedzi zaznaczonych na ujemnych punktach skali. Odpowiedzi zaznaczone jako 0, stworzyły kategorię ,,ani tak, ani nie".

Źródło: Badania własne. 


\section{Wyniki badań nad typologią gospodarstw domowych na Słowacji}

W wyniku przeprowadzonych analiz wyodrębniono, podobnie jak w przypadku gospodarstw domowych $\mathrm{z}$ województw mazowieckiego i śląskiego, trzy względnie homogeniczne typy gospodarstw domowych. Wielkość uzyskanych typów (liczba obserwacji w każdym typie) wraz z ich nazwami zaprezentowana została w tabeli 3.

Tabela 3. Nazwy i wielkości wyodrębnionych typów - Słowacja

Table 3. Names and sizes of extracted types - Slovakia

\begin{tabular}{c|l|c|r}
\hline Klaster / Typ & \multicolumn{1}{|c|}{ Nazwa } & Liczba obserwacji & Procent obserwacji \\
\hline I & Umiarkowanie zainteresowani & 130 & 43,3 \\
\hline II & $\begin{array}{l}\text { Pasywni, nie przywiązujący dużej wagi do } \\
\text { żywności i żywienia }\end{array}$ & 54 & 18,0 \\
\hline III & Aktywni i racjonalni & 116 & 38,7 \\
\hline \multicolumn{1}{c|}{ Ważne } & 300 & 100,0 \\
\hline \multicolumn{2}{l}{ Braki } & 0 & 0,0 \\
\hline
\end{tabular}

Źródło: Badania własne.

W pierwszej wyodrębnionej grupie (typ I) znalazły się gospodarstwa domowe, które generalnie zwracają uwagę na kwestie żywności i żywienia, ale nie są przesadnie nimi zainteresowane. Jest to typ gospodarstw, w którym zaobserwowano najwięcej odpowiedzi neutralnych (0), znajdujących się w środku siedmiostopniowej skali. Nie oznacza, to jednak, że kwestie żywności i żywienia są im zupełnie obojętne. Ponad 3/4 gospodarstw domowych w tej grupie podczas zakupu żywności zwraca uwagę na termin jej przydatności do spożycia, na jej walory smakowo-zapachowe, jej cenę. Podobny odsetek dokonuje zakupów u sprzedawców do których ma zaufanie. W widocznym stopniu gospodarstwa te nie są jednak zainteresowane zakupem żywności przez internet $(82,3 \%)$, pozyskiwaniem i przekazywaniem informacji o nowych ofertach żywnościowych $(41,5 \%)$, czy nabywaniem żywności na podstawie wcześniej przygotowanej listy zakupów (35,4\%). Gospodarstwa domowe typu I to najczęściej gospodarstwa 2- i 3-osobowe (odpowiednio: 26,9\% i 27,7\%), deklarujące najczęściej przeciętną sytuację materialną $(34,7 \%)$ i zamieszkujące miasta liczące od 50 do 100 tys. mieszkańców (34,7\%). Są to gospodarstwa częściej, niż w innych typach, tworzone przez panie domu w wieku 35 lat i młodszym $(32,5 \%)$. W tym typie gospodarstw najczęściej $\mathrm{z}$ pośród pozostałych o wyborze danych artykułów żywnościowych decydują wszyscy domownicy (13,0\%), mimo tego zakupy i przygotowanie posiłków najczęściej spoczywa na barkach pań domu (odpowiednio 66,1\% i 74,7\%). Żywność ekologiczną i wygodną spożywa się w tych gospodarstwach najczęściej od czasu do czasu - okazjonalnie (zadeklarowało tak odpowiednio 35,7\% i 38,8\% gospodarstw w tej grupie). Bardzo często spożywana jest natomiast żywność funkcjonalna i przetwory domowe. Codziennie lub kilka razy w tygodniu żywność funkcjonalna spożywana jest w 41,5\% gospodarstw typu I, a przetwory domowe w 60,7\%. Gospodarstwa tworzące typ I można by zatem określić mianem „umiarkowanie zainteresowanych”. W pobranej próbie stanowią największy odsetek badanych - 43,3\%. 
Tabela 4. Charakterystyka wyodrębnionych typów gospodarstw domowych według ich zachowań na rynku żywności - Słowacja ( $\mathrm{N}=300, \mathrm{w} \%)$

Table 4. Characteristics of extracted types of households according to their behaviour on the food market Slovakia $(\mathrm{N}=300$, in \%)

\begin{tabular}{|c|c|c|c|c|}
\hline \multirow{2}{*}{ Wyszczególnienie } & \multirow{2}{*}{ Odpowiedź } & \multicolumn{3}{|c|}{ Typy gospodarstw domowych } \\
\hline & & I & II & III \\
\hline \multirow{3}{*}{$\begin{array}{l}\text { Zakupu żywności dokonujemy na podstawie } \\
\text { wcześniej sporządzonej listy produktów. }\end{array}$} & twierdząca & 50,8 & 39,1 & 81,0 \\
\hline & ani tak ani nie & 13,8 & 10,9 & 11,2 \\
\hline & przecząca & 35,4 & 50,0 & 7,8 \\
\hline \multirow{3}{*}{$\begin{array}{l}\text { Przy zakupie żywności zwracamy uwagę na jej } \\
\text { składniki. }\end{array}$} & twierdząca & 53,1 & 10,9 & 87,1 \\
\hline & ani tak ani nie & 16,2 & 6,5 & 8,6 \\
\hline & przecząca & 30,8 & 82,6 & 4,3 \\
\hline \multirow{3}{*}{$\begin{array}{l}\text { Przy zakupie żywności zwracamy uwagę na } \\
\text { termin przydatności do spożycia. }\end{array}$} & twierdząca & 79,2 & 23,9 & 96,6 \\
\hline & ani tak ani nie & 13,8 & 15,2 & 2,6 \\
\hline & przecząca & 6,9 & 60,9 & 0,9 \\
\hline \multirow{3}{*}{$\begin{array}{l}\text { Przy zakupie żywności zwracamy uwagę na jej } \\
\text { walory smakowo-zapachowe. }\end{array}$} & twierdząca & 79,2 & 30,4 & 94,8 \\
\hline & ani tak ani nie & 12,3 & 17,4 & 3,4 \\
\hline & przecząca & 8,5 & 52,2 & 1,7 \\
\hline \multirow{3}{*}{$\begin{array}{l}\text { Przy zakupie żywności zwracamy uwagę na jej } \\
\text { cenę. }\end{array}$} & twierdząca & 76,9 & 65,2 & 86,2 \\
\hline & ani tak ani nie & 11,5 & 8,7 & 3,4 \\
\hline & przecząca & 11,5 & 26,1 & 10,3 \\
\hline \multirow{3}{*}{$\begin{array}{l}\text { Żywność kupujemy w sklepach, do których } \\
\text { mamy zaufanie. }\end{array}$} & twierdząca & 76,9 & 56,5 & 94,0 \\
\hline & ani tak ani nie & 12,3 & 19,6 & 0,9 \\
\hline & przecząca & 10,8 & 23,9 & 5,2 \\
\hline \multirow{3}{*}{ Kupujemy żywność przez internet. } & twierdząca & 8,5 & 4,3 & 10,3 \\
\hline & ani tak ani nie & 9,2 & 2,2 & 5,2 \\
\hline & przecząca & 82,3 & 93,5 & 84,5 \\
\hline \multirow{3}{*}{$\begin{array}{l}\text { Przy zakupie żywności zwracamy uwagę na } \\
\text { rodzaj opakowania. }\end{array}$} & twierdząca & 40,8 & 15,2 & 61,2 \\
\hline & ani tak ani nie & 27,7 & 13,0 & 17,2 \\
\hline & przecząca & 31,5 & 71,7 & 21,6 \\
\hline \multirow{3}{*}{$\begin{array}{l}\text { Przy zakupie żywności zwracamy uwagę na jej } \\
\text { pochodzenie. }\end{array}$} & twierdząca & 59,2 & 8,7 & 98,3 \\
\hline & ani tak ani nie & 17,7 & 6,5 & 1,7 \\
\hline & przecząca & 23,1 & 84,8 & . \\
\hline \multirow{3}{*}{$\begin{array}{l}\text { Informujemy się o nowych ofertach } \\
\text { żywnościowych. }\end{array}$} & twierdząca & 34,6 & 15,2 & 75,0 \\
\hline & ani tak ani nie & 23,8 & 6,5 & 13,8 \\
\hline & przecząca & 41,5 & 78,3 & 11,2 \\
\hline \multirow{3}{*}{$\begin{array}{l}\text { Przed zakupem zastanawiamy się czego } \\
\text { potrzebujemy. }\end{array}$} & twierdząca & 63,8 & 50,0 & 91,4 \\
\hline & ani tak ani nie & 12,3 & 15,2 & 6,0 \\
\hline & przecząca & 23,8 & 34,8 & 2,6 \\
\hline
\end{tabular}

Uwaga: jak w tab. 2.

Źródło: Badania własne.

Drugi wyodrębniony typ gospodarstw domowych, stanowią jednostki, najmniej aktywne i najmniej zainteresowane kwestiami żywności i żywienia. Na wszystkich bowiem 11 itemach skali stanowiącej podstawę przeprowadzanej typologii, najczęściej ze wszystkich wyodrębnionych grup zaznaczały odpowiedzi negatywne $(-3,-2,-1)$. Szczególnie było to widoczne $\mathrm{w}$ takich kwestiach, jak zakup żywności przez internet (93,5\% odpowiedzi negatywnych), zainteresowanie pochodzeniem żywności $(84,8 \%)$ i jej składem (82,6\%), a także informacjami o ofertach żywnościowych $(78,3 \%)$ czy rodzajem opakowania nabywanej żywności $(71,7 \%)$ - tab. 4 . W gospodarstwach typu II stosunkowo najrzadziej spożywana jest żywność ekologiczna, funkcjonalna i domowe przetwory. Żywność ekologiczną 34,4,\% gospodarstw tego typu spożywa tylko okazjonalnie, a 21,9,\% nie je jej wcale. Żywność funkcjonalną - 25,2\% je okazjonalnie, 18,2\% - wcale. Domowe 
przetwory - 20,0\% okazjonalnie, 4,4\% - wcale. Najczęściej spożywana jest natomiast żywność wygodna (59,9\% przynajmniej kilka razy w miesiącu lub częściej). W gospodarstwach II typu najwięcej znalazło się gospodarstw jednoosobowych $(17,4 \%)$ prowadzonych głównie przez mężczyzn. Duży odsetek stanowią także gospodarstwa domowe 5- i więcej osobowe (30,8\%), w których Panie domu liczą 50 i więcej lat $(38,0 \%)$, aktywnych zawodowo z dorosłymi dziećmi pozostającymi we wspólnym gospodarstwie domowym. Gospodarstwa te, częściej niż pozostałe, funkcjonują na wsiach i w małych miastach (do 50 tys. mieszkańców). Z tych klas miejscowości pochodzi łącznie ponad połowa gospodarstw typu II. Gospodarstwa te stanowią najmniejszą grupę spośród wyróżnionych (18,0\% ogółu badanych). Określić można by je mianem ,pasywnych, nie przywiązujących dużej wagi do żywności i żywienia".

Gospodarstwa domowe skupione w ostatnim, III typie, określić można by mianem „aktywnych i racjonalnych”. Stanowią one drugą, co do wielkości, wyodrębnioną grupę gospodarstw (47,0\% ogółu badanych) - tab. 3. Wydają się być najbardziej zainteresowane prawidłowym odżywianiem. Są też najbardziej aktywne na rynku żywności. Dość powiedzieć, że ponad 90\% tego typu gospodarstw przy zakupie żywności zwraca uwagę na jej pochodzenie, termin przydatności do spożycia, walory smakowo-zapachowe oraz czy sprzedawca jest godny zaufania. Najczęściej też, spośród badanych gospodarstw, deklarują dokonywanie zakupów żywności przez internet $(10,1 \%)$ - tab. 4. Są to jednostki częściej, niż w innych typach, tworzone przez panie domu w wieku 36 - 49 lat (46,2\%). To głównie gospodarstwa domowe 4-osobowe $(31,0 \%)$, z większych miast (powyżej 100 tys. mieszkańców -41,4\%). W tym typie gospodarstw, najczęściej z pośród pozostałych typów, o wyborze spożywanej żywności decydują panie domu $(73,2 \%)$, najczęściej też gotuja (78,3\%). Warto jednak zauważyć, że mimo tego zakupów żywności w 30\% przypadków dokonują tutaj mężczyźni. Spośród wyodrębnionych grup gospodarstw domowych, członkowie jednostek typu III najczęściej spożywają żywność ekologiczną $(67,8 \%$ przynajmniej kilka razy w miesiącu i częściej) oraz domowe przetwory $(91,4 \%)$. Niestety najwięcej też spośród wszystkich typów spożywają żywności wygodnej (68,1\%). Żywność funkcjonalna konsumowana jest $\mathrm{w}$ tych gospodarstwa $\mathrm{z}$ umiarkowaną częstotliwością (31,3\% - kilka razy w miesiącu).

\section{Podsumowanie}

Tak przedsiębiorstwa chcące odnieść sukces rynkowy, jak i różnego rodzaju instytucje odpowiadające za kształtowanie polityki gospodarczej powinny w sposób ciagły monitorować zachowania gospodarstw domowych, szczególnie na takim rynku, jakim jest rynek artykułów żywnościowych - rynek, na którym konsumenci dążą do realizacji swoich podstawowych potrzeb zaspokojenia głodu i pragnienia. Wielkie zróżnicowanie preferencji, motywów konsumpcji, posiadanej siły nabywczej, jak i wreszcie samych zachowań gospodarstw domowych wynikających z ich uwarunkowań wewnętrznych i zewnętrznych powoduje dużą trudność w przewidywaniu zachowań nabywczych i konsumpcyjnych tych podmiotów. Pewnym rozwiązaniem może być przeprowadzenie typologii gospodarstw domowych, przez co można zredukować miliony podmiotów do kilku określonych typów charakteryzujących się swoistymi cechami i zachowaniami. Można także, co nie jest mniej istotne, określić wielkość i miejsca występowania każdego z wyodrębnionych typów. 
Celem niniejszego artykułu była próba przeprowadzenia empirycznej typologii gospodarstw domowych ze względu na ich zachowania na rynku artykułów żywnościowych. Podjęto dwie takie próby. Do pierwszej posłużyły wyniki badań zachowań gospodarstw domowych $\mathrm{z}$ województw mazowieckiego i śląskiego - do drugiej zachowań gospodarstw domowych ze Słowacji. W obu przypadkach wyodrębniono po trzy typy gospodarstw względnie podobnych do siebie w ramach danego typu i różniących się między typami. Typologia gospodarstw domowych $\mathrm{z}$ województw mazowieckiego $\mathrm{i}$ śląskiego pozwoliła wyodrębnić typ świadomych i racjonalnych konsumentów, interesujących się tym, co jedzą i gdzie nabywają żywność, typ gospodarstw zainteresowanych troską o zdrowe odżywianie i starających się zachowywać racjonalnie, ale zagonionych i zajętych innymi sprawami, wreszcie typ gospodarstw wygodnych, nie przywiązujących większej wagi do nabywanej i konsumowanej żywności. W podobny sposób można scharakteryzować wyodrębnione typy gospodarstw domowych ze Słowacji. Tam te podziały wydają się być jeszcze bardziej ostre i wyraźne. Z jednej strony gospodarstwa domowe bardzo aktywne na rynku żywności i świadome - $z$ drugiej pasywne, niemal obojętne na to co nabywają i spożywają. Uzyskane wyniki są częściowo zbieżne z typami wyodrębnionymi przez zespół Kieżel, który przeprowadzając typologię konsumentów w latach 90 . XX wieku na rynku żywności wyodrębnił trzy typy konsumentów: tradycjonalistów, zachowujących się racjonalnie i rozważnie oraz innowatorów (Smyczek i Sowa, 2005). Pewne podobieństwa, ale także różnice można dostrzec $\mathrm{w}$ typach zachowań konsumentów na rynku żywności wyodrębnionych przez zespół pracowników IRWiK w 1987 roku. W wyniku dokonanej delimitacji uzyskano cztery typy badanych jednostek: tradycjonalny, aktywny, umiarkowanie racjonalny oraz racjonalny, rozwojowy (Kusińska 2009). Autor ma jednak pełną świadomość, że do zaprezentowanych przez niego wyników badań należy podchodzić z ostrożnością z uwagi na obciążenia błędem pomiaru wynikającym przede wszystkim z nielosowego doboru próby, jej wielkości, jak i też stosunkowo wąskiego obszaru prowadzonych badań. Ma jednak nadzieje, że choć $\mathrm{w}$ pewnym stopniu przyczynia się do podkreślenia wagi i znaczenia prowadzenia badań typologicznych gospodarstw domowych mogących przynieść duże korzyści poznawcze nauce i wymierne korzyści gospodarce.

\section{Literatura}

Barska, A. (2019). Konsumenci pokolenia milenium na rynku innowacyjnych produktów żywnościowych na obszarach przygranicznych Polski, Niemiec, Czech i Słowacji (Consumers of the millennium generation on the market of innovative food products in the border areas of Poland, Germany, the Czech Republic and Slovakia). Zielona Góra: Uniwersytet Zielonogórski.

Bywalec, Cz. (2009). Ekonomika i finanse gospodarstw domowych (Economics and Finance of Households). Warszawa: Wydawnictwo Naukowe PWN.

CCA (2019). Définition: Styles de vie. Pobrane 20 sierpnia 2019 z: https:// www. definitionsmarketing.com/definition/Styles-de-vie/.

Diansheng, D., Hayden, S. (2012). Modeling A Household's Choice among Food Store Types. American Journal of Agricultural Economics, 94(3), 702-717. DOI: 10.1093/ajae/aas013.

Di Talia, E., Simeone, M., Scarpato, D. (2019). Consumer behaviour types in household food waste. Journal of Cleaner Production, 214, 166-172. DOI: 10.1016/j.jclepro.2018.12.216.

Everitt, B.S., Landau, S., Leese, M., Stahl, D. (2011). Cluster Analysis, $5^{\text {th }}$ Edition, Wiley Series in Probability and Statistics, London: John Wiley and Sons Ltd. 
Gardocka-Jałowiec, A. (2015). Gospodarowanie środkami konsumpcji a zdolność kreowania działalności innowacyjnej w gospodarce (Consumption Resources Management and the Ability to Create Innovative Activity in the Economy). Marketing $i$ Rynek, 2 (CD), 37-48.

Gatnar, E., Walesiak, M. (red.). (2009). Statystyczna analiza danych z wykorzystaniem programu R (Statistical analysis of data using the R program). Warszawa: Wydawnictwo Naukowe PWN

Gutkowska, K., Ozimek, I., Laskowski, W. (2001). Uwarunkowania konsumpcji w polskich gospodarstwach domowych (Determinants of consumption in Polish households). Warszawa: Wydawnictwo SGGW.

Henson, R.K. (2001). Understanding internal consistency reliability estimates: A conceptual primer on coefficient alpha. (Methods, plainly speaking). Measurement and Evaluation in Counseling and Development, 34(3), 177-189.

Jaciow, M., Wolny, R. (2011). Polski e-konsument. Typologia i zachowania (Polish e-consumer. Typology and behaviours). Gliwice: Helion.

Jaciow, M. (2018). Ekwiwalencja w międzynarodowych badaniach rynku (Equivalence in international market research). Katowice: Wydawnictwo Uniwersytetu Ekonomicznego w Katowicach.

Jaensch, E. (1928). On the Methods of Psychological Typology. Zeitschrift Für Psychologie Und Physiologie Der Sinnesorgan, 108, 1-16.

Kieżel, E. (red.). (2010). Konsument i jego zachowania na rynku europejskim (The Consumer and His Behavior on the European Market). Warszawa: PWE.

Komor, M. (2000). Euromarketing. Strategie marketingowe przedsiębiorstw na eurorynku (Euromarketing. Marketing strategies of enterprises on the Euromarket). Warszawa: Wydawnictwo Naukowe PWN.

Komor, M. (2011). Segmentacja europejskich konsumentów według stylu życia (Segmentation of European consumers by lifestyle). Marketing i Rynek, 7, 14-19.

Kruger, K.V., (2014). Personal Consumption by Family Type and Household Income. Journal of Forensic Economics, 25(2), 203-220. DOI: 10.5085/0898-5510-25.2.203.

Kusińska, A. (1990). Typologia konsumentów a projektowanie produktu (Consumer typology and product design) Warszawa: Instytut Wzornictwa Przemysłowego, Prace i Materiały, zeszyt 139.

Kusińska, A. (1992). Typologia konsumentów według zachowań na rynku jako przesłanka decyzji gospodarczych (Typology of consumers according to market behavior as a premise for economic decisions). Warszawa: IRWiK.

Kusińska, A. (2009). Segmentacja rynku i typologia konsumentów (Market Segmentation and Consumer Typology). Warszawa: Instytut Badań Rynku, Konsumpcji i Koniunktur.

Kusińska, A. (2014). Analizy wielowymiarowe jako źródło wiedzy o zachowaniach konsumentów na rynku (Multidimensional Analysis as a Source of Knowledge About Consumer Behaviour). Prace Naukowe Uniwersytetu Ekonomicznego we Wrocławiu, 336, 89-98.

Magadze, A.A., Obadire, O.S., Maliwichi, L.L., Musyoki, A., Mbhatsani H.V. (2017). An Assessment of Types of Foods Consumed by Individuals in Selected Households in South Africa. Gender \& Behaviour, 15 (4), 10610-10626.

Maslow, A.H. (2018). Motywacja a osobowość (Motivation and Personality). Warszawa: Wydawnictwo Naukowe PWN.

Myers, J.G., Nicosia, F.M. (1968). Study Of Consumer Typologies. Journal of Marketing Research, 5(2), 182 193.

Nowak, S. (2012). Metodologia badań społecznych (Methodology of social research). Warszawa: Wydawnictwo Naukowe PWN.

Oppenheim, S. (1911). On the Typology of the Primate Cranium. Zeitschrift Fur Morphologie Und Anthropologie, $14,1-203$.

Piekut, M. (2008). Polskie gospodarstwa domowe - dochody, wydatki i wyposażenie w dobra trwałego użytkowania (Polish households - income, expenses and equipment with durable goods). Warszawa: Wydawnictwo SGGW.

Piekut, M. (2017). Wzorce konsumpcji według typów wiejskich gospodarstw domowych w latach 2004-2014 (Patterns of consumption by types of rural households in 2004-2014). Warszawa: Difin.

PWN (2019), Typologia. Encyklopedia PWN. Pobrane 20 sierpnia 2019 z: https://encyklopedia.pwn.pl/ encyklopedia/typologia; $1 . h$ tml.

Saran, J. (2014). Klasyfikacje i typologie jako sposoby uprawiania empirycznych badań pedagogicznych (Classifications and typologies as ways of doing empirical pedagogical research). Studia $i$ Prace Pedagogiczne, (1), 13-30.

Shuey, H. (1937). The fundamental principles of typology. Psychological Review, 44, 170-182.

Smyczek, S., Sowa, I. (2005). Konsument na rynku. Zachowania, modele, aplikacje (Consumer on the Market. Behaviors, Models, Applications). Warszawa: Difin. 
Sowa, I. (2018). Racjonalność zachowań jako podstawa typologii polskich konsumentów (Rationality of Behaviours as the Basis for Typology of Consumers). Handel Wewnętrzny, 4(375), 340-351.

Światowy, G. (2006). Zachowania konsumentów (Consumer behaviours). Warszawa: PWE.

Światowy, G. (2012). Gospodarstwo domowe jako kreator przemian społecznych i gospodarczych (Household as a Creator of Socio-Economic Transformations). Konsumpcja i Rozwój, 2(3), 56-66.

Von Ginneken, J.P. (1907). Study of the Typology of Languages. Anthropos, 2(4-5), 690-707.

Walesiak, M. (red.). (2004). Metody statystycznej analizy wielowymiarowej w badaniach marketingowych (Methods of statistical multivariate analysis in marketing research). Wrocław: Wydawnictwo Akademii Ekonomicznej im. Oskara Langego we Wrocławiu.

Do cytowania / For citation:

Maciejewski G. (2020). Typy gospodarstw domowych ze względu na ich zachowania na rynku żywności. Problemy Rolnictwa Światowego, 20(1), 52-66; DOI: 10.22630/PRS.2020.20.1.5

Maciejewski G. (2020). Types of Households by Their Behaviour on the Food Market (in Polish). Problems of World Agriculture, 20(1), 52-66; DOI: 10.22630/PRS.2020.20.1.5 